\title{
PROBLEMS OF CANCER TREATMENT
}

\author{
PART I \\ THEORY OF TREATMENT BASED ON KNOWN MECHANISMS OF \\ ANTICANCER IMMUNOLOGICAL RESPONSES
}

Jerzy KAWIAK ${ }^{1}$, Grazyna HOSER ${ }^{2}$, Joanna DOMAGAŁA-KULAWIK ${ }^{3}$
${ }^{1} \mathrm{M}$. Nałęcz Institute of Biocybernetics and Biomedical Engineering, PAN, Warsaw
${ }^{2}$ Laboratory of Cytometry, Centre for Postgraduate Medical Education, Warsaw
${ }^{3}$ Chair and Department of Internal Diseases, Pneumonology and Allergology, Warsaw Medical University

\section{DOI: $10.1515 /$ acb-2017-0006}

Summary: Various processes, taking place both in cells and in their environment, are linked to carcinogenesis. This paper aims at recalling the complex mechanisms of oncogenesis, with particular attention paid to responses of the immune system. In development of solid tumours, leukaemias and lymphomas several common stages can be noted. A neoplastic disease cannot be understood considering only phenomena of genetic mutations. Neoplastic cells are characterised by an extensive antigenic variability and resistance to apoptosis. The cells create around them a microenvironment which protects them from defensive activity of the host. In the paper we present the recognised mechanisms of anti-neoplastic defense as well as several elements allowing the solid tumours and leukaemias to escape from the immune surveillance. The generally accepted treatment of tumours aims at reducing numbers of tumour cells. Following resection of a tumour, radiotherapy or chemotherapy, the parallel or consecutive stage of treatment was found to involve an increase in number of clones of immune system cells. One of the ways in which the immune system can be activated involves autovaccination of the host with own neoplastic cells in an apoptosis. However, attempts of such a therapy frequently brought no expected results due to blocked activity of cytotoxic cells. Therefore, the subsequent stage in activation of the immune system should involve elimination of the tumor-mobilized blockade of the system. Attempts toward this aim include neutralization of the tumour-blocked cytotoxic properties of defensive cells, first of all $\mathrm{T}$ lymphocytes. The recognized mechanisms of blocking $\mathrm{T}$ cells activity in the PD-1/PD-L1 system or due to inhibition of activation by CTLA-4 molecule provided rationale for development of effective tumour immunotherapy approaches.

Keywords: targeted therapy, lung cancer, leukaemias, tumour microenvironments, suppressor cells, tumour markers 
Abbreviations: ADCC - antibody dependend cell cytotoxicity; AML - acute myeloid leukaemia; APC - antigen presenting cell; BAL - bronchoalveolar lavage; BTLA - B, T lymphocyte attenuator, CD272; CLL - chronic lymphocytic leukaemia; CML - chronic myeloid leukaemia; CRAM - chemokine receptor on activated macrophages (known also as HCR or CCRL2); CTLA-4 - cytotoxic T lymphocyte antigen, CD152; CTLs - cytotoxic T lymphocytes; DAMPs - danger (damage) -associated molecular patterns; DCs - dendritic cells; EGFR - epidermal growth factor receptor; EMT - epithelial mesenchymal transition; EOC - epithelial ovarian cancer; EpCAM - Epithelial cell adhesion molecule; Foxp3 - forkhead box P3-transcription - transcription factor Foxp3; HMGB1 - high- mobility group box-1; HSP - heat shock protein; IL - interleukin; LAG-3 - lymphocyte activation gen-3; M1,M2 macrophage subpopulations M1, M2; MAGE - A3 melanoma associated antigen, MDM2 - murine double minute2 - mouse protein MDM2 (E3 ubiquitin ligase); MDSCs - myeloid derived suppressor cells; MHC - major histocompatibility complex; MMP - metalloproteinase; MUC1 - Mucin 1, cell surface associated; NK - natural killer cells; NKT - natural killer T cells; NO - nitric oxide; PD-1 - programmed cell death protein1, CD279; PD-L1, PD-L2 - ligand for PD-1; COPD - chronic obturative pulmonary disease; ROS - radical oxygen species; TAM - tumour associated macrophages; TAN - tumour associated neutrophils; TATE - tumour associated tissue eosinophils; TCR - T cell receptor; TGF $\mathbf{\beta}$ - transforming growth factor $\beta$; $\mathbf{T h}$ - Thelper lymphocytes; $\mathbf{T c}-$ T cytotoxic lymphocytes; TIL - tumour infiltrating lymphocytes; Tim3 - mucin domain-containing molecule-3 - transmembrane immunoglobulin and mucin 3; TIMP1 - tissue inhibitors of metalloproteinase-1; TNF - tumour necrosis factor; Tregs - regulatory T lymphocytes

\section{INTRODUCTION}

Aside from cardiovascular diseases, tumours represent the most frequent cause of death. This study aims at summing up the till now available chances for treatment and presenting principles of immunotherapy, which may asssist the classical therapy of tumours. At present a tendency is observed of diagnosing not only the tumour type and its markers but also condition of the host immune system which may point to an individual prognosis of the disease course [59]. This paper aims not at providing details of the treatment but at reviewing problems associated with therapies planned to control and to activate immune system of patients.

\section{HOW TUMORS ARISE - THE EXAMPLE OF LUNG CANCER AND LEUKAEMIAS}

Neoplastic tumours develop in several stages, well described in, e.g. colorectal carcinoma in humans and dermal melanoma in mice $[3,16,78]$.

Post-translational modifications of histons, methylation and demethylation of bases in nucleic acids, similarly to changes in nucleotide sequence, translocation of chromosomal segments lead to activation or inactivation of numerous genes. The epigenetic changes may stably re-program cells, which aquire phenotype of neoplastic cells [111]. Cells with mutations, transformed ones, may compete 
with each other, leading to cell selection. Gradually forming a small focus or intraepithelial lesions, e.g. a dysplatic focus. Developing tumors consist not only of transformed cells but also of numeorus untransformed cells of their sublayer and immune system. At the early stages of oncogenesis host's immune system recognizes and responds to presence of the altered cells while further development of the tumour depends on alterations in immunogenic properties of cancer cells [91]. Survival of the transformed cells is linked to their adaptive response to environmental conditions [106].

Most of tumours contains a variable fraction of cells manifesting markers of stem cells [113], recently with increasing frequency termed the tumour propagating cells. The cells manifest genome instability. High levels of oxygen reactive forms in the cells result in injuries of DNA, leading to accumulation of consecutive chromosomal aberrations [99]. Origin of the cells remains unclear although they are identified using surface markers, including, among other, CD133, CD44, CD29. Considering high variability of neoplastic cells it remains disputable if such cells can be distinguished [136].

\section{AVOIDANCE OF TUMOUR RECOGNITION BY CELLS OF IMMUNE SYSTEM - THE EXAMPLE OF LUNG CANCER}

Lung cancer presents a typical example of a solid tumor, on which the above mentioned disturbances can be characterised. Also the epidemiological data justify a broader presentation of the tumour The tumour provides the principal cause of death due to malignant processes in both genders [31]. The respective annual incidence exceeds worldwide 1600000 while the combat with the disease is won by just around $15 \%$ patients. The very rapid and extremely deceitful course of lung cancer causes that at the moment of diagnosis over $70 \%$ of the tumours manifests a significant advancement, making impossible causal, particularly operative treatment $[20,31]$. Surgery remains the only effective method of treatment in most of solid tumours, including non-small cell pulmonaty cancer, apart of few histological types which are sensitive to chemotherapy, like, e.g., small-cell lung cancer $[52,57]$. The lack of possibilities and inefficacy of classical therapeutic approaches justifies an extensive search for new therapeutic approaches including a targeted therapy and an immunomodulatory treatment.

Similarly to other tumours, in lung cancer the primary antineoplastic response is effective at the phase of a very early oncogenesis [1,9]. The hypothesis of immune surveillance of Burnet and Thomas (1957) assumes a destruction of altered, pathological cells and a continuous protection of the host against neoplasia. Currently, tumour development is thought to be significantly modified by the immune system. In the process, an important role is ascribed to tumour- 
infiltrating inflammatory cells [30]. However, the primarily effective immune surveillance becomes altered in a very refined way by a weakened recognition of cancerous cells, a reduced function of antigen presentation and by a prevalence of an inhibitory over the activating immune response $[1,26]$. The principal mechanisms by which a tumour sneaks through the immune surveillance are presented in fig. 1 .

Most of solid tumours, including in particular lung cancer, affects patients of an advanced age, in whom a cummulation developes also of harmful effects of external conditions, including tobacco smoke, the principal risk factor for development of lung cancer [22, 49]. The investigated topics include also phenomena linked to effects of oxydative stress, which accelerate physiological processes of senescence, including senescence of cells in immune system, termed „inflamm-aging" [33]. Accvording to suggestions of Franceschi, in the course of senescence the decaying cells release stress factors, which additionally stimulate the immune system. This results in a certain exhaustion of defensive functions. Senescence of the immune system is associated with increased concentrations of IL-8, IL-6, TNF $\alpha$, and, in parallel, decreased concentrations of IL-2 are detected [33]. T lymphocyte polarizations is shifted toward Th2 type responses. Phenotype of NK cells undergoes a change, accompanied by a reduction in their cytotoxic potential. The senescence of immune system is expressed in a loss of its ability to recognise foreign and own antigens. The sphere of such disturbances closely resembles alterations observed in the course of neoplastic diseases $[33,36]$.

FIGURE 1. Scheme of mechanism of a cytotoxic anti-neoplastic reaction and its inhibition a) Cytotoxic cells (CTLs) following stimulation induce apoptosis of a neoplastic cell

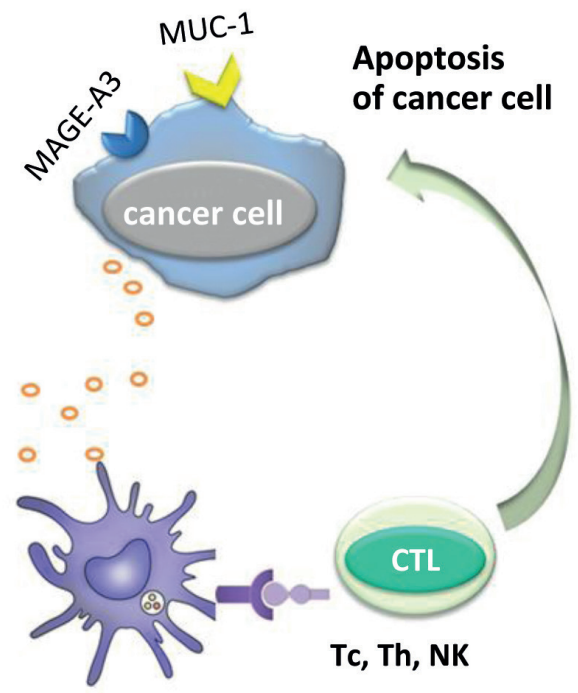


b) Inhibition of lymphocytes by PD-1 and CTLA- 4 molecules prevents against a cytotoxic reaction

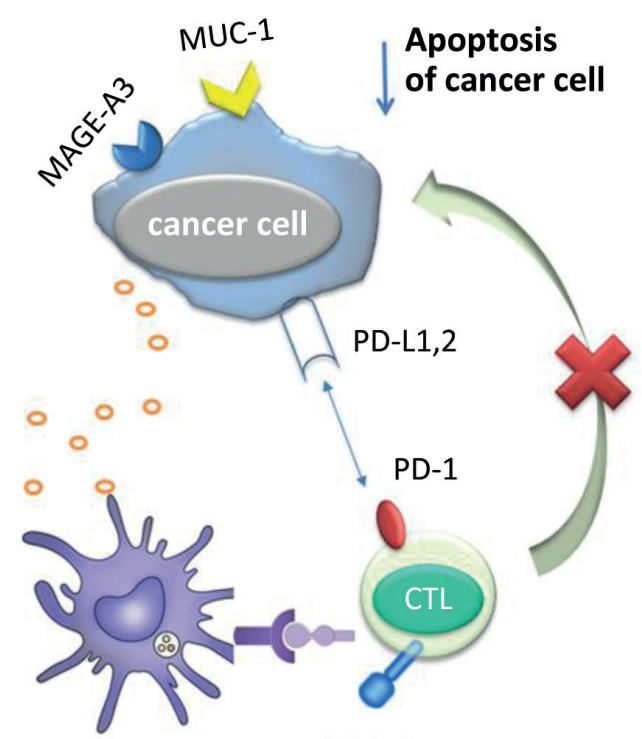

CTLA-4

c) In addition, the cytotoxic response becomes controlled and an immune tolerance develops with involvement of cells with controlling properties: Treg, M2 and MDSCs and cytokines, TGF $\beta$, Il-10

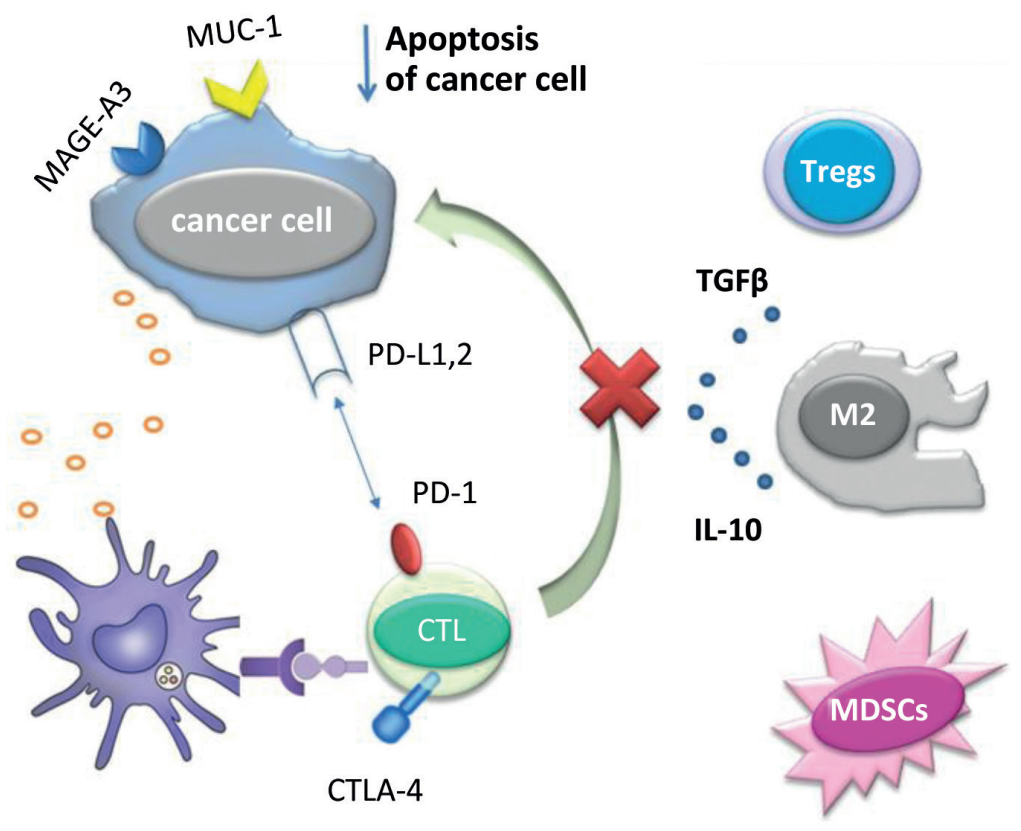




\section{MARKERS OF NEOPLASTIC CELLS ON THE EXAMPLE OF LUNG CANCER}

Cells of lung cancer are characterized by poorly defined and variable antigenicity, which causes extensive histopathological heterogenicity. The best known antigens, the presence of which is reproducibly detected include MAGE-A3 (melanoma associated antygen) and MUC1. MAGE-A3 is detected in 35-50\% patients with non-small cellular lung cancer, mainly of the squamocellular type. Expression of the antigen is linked to a poor prognosis. MAGE-A3 recognised by cytotoxic cells provides ground for production of numerous vaccines [88]. In clinical trials the need is stressed for confirmation of expression of the antigen on tumour cells before treatment. Glycoprotein MUC1 is commonly present on cancer cells in glandular type tumours and its expression also is linked to an unfavourable prognosis. Ita extracellular domain, MUC1 is strongly immunogenic, proangiogenic, it intensifies migration of tumour cells and their resistance to apoptosis [155]. The subsequent therapeutic target involves receptor for epithelial growth factor (EGFR) commonly present on cells of lung cancer [77]. Its activity can be inhibited using CIMAvax vaccine, taking advantage of the antibody specific for EGFR [89]. Until now, few recognised epitopes of cancer cells were described [121], such as, for example, peptides in patients with melanoma [21, 46] and in ovarian cancer [114]. Due to mutations taking place in cancer cells development of a solid tumour is accompanied relatively dynamic appearance of new antigens, changes in surface markers develop or the antigens become masked. The cancer cells become "unrecognisable" for the immune system and, therefore, no conditions exist for development of the acquired immunity mechanisms. Nevertheless, as recently demonstrated, the therapies applied in lung cancer, chemotherapy, radiotherapy or even a targeted therapy, promote stimulation of a reaction due to ,uncovering" the antigens and formation of neo-antigens in effect of a certain cellular stress [145]. The phenomenon carries significant therapeutic implications for the currently executed clinical trials in which immunotherapy is accompanied by chemotherapy [138].

\section{DEVELOPMENT OF SYSTEMIC TUMOURS ON THE EXAMPLE OF B-LYMPHOCYTE LEUKAEMIA}

Also systemic tumours of leukaemia/lymphoma type escape from immune control. Their very early stages remain unknown but considering behaviour of cells in one of leukaemias (chronic B-cell laukaemia) [90, 146], certain hypotheses can be suggested. Normal B lymphocytes of $\mathrm{CD} 19^{+} \mathrm{CD}^{+}$subpopulation continuously 
produce antibodies and in that function require no activation by $\mathrm{T}$ lymphocytes. Cells of the subpopulation provide origin for the leukaemia. Most of circulating leukaemic lymphocytes are stopped in the cell cycle at the G0/G1 phase and, therefore, accumulation of increasing numbers of lekaemic cells is thought to result from their resistance to apoptosis induced in them during normal senescence rather than from their frequent divisions [17, 19]. Elongation of the cell cycle leads to cummulation of mutations in the cells and to manifestation of traits later characterizing leukaemic cells [69]. The mutated $\mathrm{B}$ CD19+ ${ }^{+} D 5^{+}$lymphocytes compete with each other and used to select individual clones of the cells, already representing the leukaemic hyperplasia.

In normal development, the microenvironment of bone marrow contains interactions of B lymphocytes with the produced by stromal cells ligands, which maintain in the bone marrow niche the progenitor cells with expression of CXCR4 receptor and c-kit $[32,95]$. Similarly to progenitor cells, leukaemic cells manifest expression of CXCR4 receptor (CD184] [10, 85]. Cells of bone marrow stroma and nurse-like cells of bone marrow continuously secrete the CXCL12 (SDF-1] ligand and in this way attract and maintain in the bone marrow niche leukaemic B lymphocytes [140] and inhibit their apoptosis. The persistent harbouring of $\mathrm{CD}_{1} 9^{+} \mathrm{CD}^{+}$lymphocytes in bone marrow causes that after some time the leukaemic cells no longer are able to produce antibodies but continue to survive in the environment. Moreover, stromal cells protect leukaemic lymphocytes from apoptosis induced by, e.g., chemotherapy. A similar environment in lymph nodes is provided to B-CLL cells by CRAM receptors, present of their surface $[14,75]$.

\section{ALTERATIONS IN TUMOR MICROENVIRONMENT}

The accumulated in a specific place cells with a modified phenotype begin to produce proteases, which hydrolyse the surrounding extracellular matrix (matrix metalloproteinases, MMP) and tissue inhibitors of metalloproteinase 1 (TIMP-1] [48, 80, 127], which leads to progression of lesions in the pre-invasive cancer (carcinoma in situ). The proteases degrade components of the intercellular matrix and basement membranes of epithelium, which promotes invasion of neoplastic cells and their appearance in the circulation [39, 123]. MMP represent endoproteases synthetised in precursor forms and activated by proteases such as plasmin. They include, i.a., collagenases (MMP1], gelatinases (MMP2, MMP9] and membrane metalloproteases (MMP14). Overexpression of the proteases is frequently linked to poor prognosis for the patient $[68,127]$.

Tumour cells induce ingrowths of blood vessels into their region. Blood supply of neoplastic tumour condition inflow of glucose to cancer cells usually 
manifesting glycolytic metabolism [41], which represents an important stage in further development on the lesion. This results in a more rapid growth of the tumour and in presence of accompanying cells of chronic inflammatory process, macrophages and lymphocytes. The tumour-infiltrating lymphocytes $\mathrm{T}$ (tumor infiltrating lymphocytes, TILs) can be expected to recognise neoplastic antigens since on their surface activation markers appear, e.g. cytotoxic lymphocytes $\mathrm{T}$ $\mathrm{CD} 8^{+}$manifest surface expression of HLA-DR and CD38, which represents an important stage in further development of the lesion [71]. Nevertheless, the cells do not function effectively as tumour-combatting cells.

A decay of neoplastic cells can also be observed. The decaying cells are rapidly recognised and phagocytosed, including also myeloid dendritic cells (mDC). Dendritic cells manifest their capacity to cross-present antigens [64, 92, 101, $108,135]$, or to present epitopes of phagocytosed cells, in this case epitopes of cancer cells with MHC class I antigens [55, 102]. Cells distinct than $\mathrm{mDC}$ do not manifest such properties. This is important inasmuch as neoplastic cells manifest an altered mechanism of presenting their own antigens and in such a situation the latter remain unrecognised. Thus, cross-presentation involves the manner due to which such behaviour on neoplastic cells does not allow them to bypass the immune recognition and epitopes of neoplastic cells can in this way be presented to virgin lymphocytes T. Following phagocytosis of decaying neoplastic cells, dendritic cells migrate to lymph nodes [104] and there, together with MHC class I, present the neoplastic epitopes to virgin lymphocytes $\mathrm{T}$ which flow through the lymph node [54]. However, such presentation of antigens by $\mathrm{mDC}$ present within a neoplastic tumour can be blocked [87, 142]. On the basis of our own studies we found that alterations in the systemic circulation differ significantly from those in the vicinity of a tumour [25]. Thus, antigens of neoplastic cells are well recognised by mechanisms of inborn and acquired (specific) immunities out of the site of the neoplastic tumour but neoplastic cells significantly modify control of immune processes in their surrounding [74] and in this way protect neoplastic cells from attack of immune system cells.

\section{PROCESS OF APOPTOSIS}

Neoplastic cells are relatively resistant to extracellular signals of apoptosis [40, 86, 120]. Apoptosis develops along two principal pathways [35]: (a) pathway of inner origin with involvement of a recognised danger, with participation of p53 protein, leading to activation of apoptotic process with involvement of mitochondria, inhibited expression of genes the products of which exert antiapoptotic effects, e.g. Bcl2, survivin [98] and (b) pathway of external origin, with activation of 
proapoptotic surface receptors (death receptors, DR) $[2,65,151]$. This second pathway can be activated from outside of the cell by proapoptotic ligands of TNF protein superfamily, like, e.g. Fas ligand (FasL) and TRAIL [2, 93]. The ligands bind to proapoptotic receptors on the surface of tarnet (cancer) cells and transmit signal for activation of procaspase- 8 , and this activates subsequent caspases responsible for the course of apoptosis. Occasionally, this extraneous activation of apoptosis amplifies in the cell the inner signalling of apoptosis with mediation of Bid proteins of Bcl family. Caspase 8, activated along the pathway of external origin splits the Bid protein, which in this form becomes transplaced to mitochondria, initiating the internal pathway of apoptosis [155]. The two pathways converge at the stage of effector caspases, which proteolytically hydrolyse and/or activate important cell proteins (e.g. DNase which induces fragmentation of DNA).

\section{TRADITIONAL APPROACH TO TUMOUR TREATMENT: CHEMOTHERAPY, RADIOTHERAPY AND THEIR ROLE IN IMMUNOTHERAPY}

Routinely, cancer tumors are treated by surgical removal, chemotherapy and radiotherapy. Additionally, in some patients immunotherapy is applied, involving administration of monoclonal antibodies directed at antigens of cancer cells. In presence of complement and cells with receptors for the Fc fragment of immunoglobulins they may directly activate death of target cells. This is an important stage of therapy, leading to reduction in cancer cell number and after such procedures many patients manifest transient improvement. However, one should be prepared for subsequent proliferation of the remaining in the patient cancer cells which propagate the tumour or for development of a new tumour, activated by chemotherapeutic agents or by radiotherapy. Chemotherapeutic agents and radiotherapy lead to DNA injuries but neoplastic cells contain more efficient than "healthy" cells mechanisms of DNA repair, which in consequence may lead to further mutations and tumour development [83], as well as to multidrug resistance $[50,82,125]$. In the course of tumour development more than $50 \%$ tumour cells due to point mutations loose function of $\mathrm{p} 53$ protein $[149,150]$, or of MDM2 protein. The MDM2 (Murine Double Minute 2) protein, a repressor of p53, undergoes a deregulation [144, 147], with the resulting appearance of various tumour types. They do not respond to therapies inducing the inner pathway of apoptosis, evoked by chemotherapeutic agents or radiotherapy. On the other hand, the external pathway of apoptosis functions independently of activity of p53 protein. Therefore, it can be employed for induction of the programmed death in neoplastic cells by $\mathrm{T}$ lymphocytes. 
Surgical removal of a tumour frequently is assisted by chemotherapy and radiotherapy. Radiotherapy is targeted at the tumour site or lymph nodes which may be occupied by tumour cells. Such procedures can be precisely targeted at neoplastic foci and they do not significantly damage the patient's immune system. Local irradiation is followed by additonal systemic interactions involving release of neoplastic antigens and the so called damage-associated molecular patterns (DAMPs). The molecules released from the damaged cells include, i.a., DNA, ATP, heat-shock proteins [HSP), high-mobility group box 1 HMGB1 proteins, components of mitochondria and extracellular heparin sulphates [73]. Radiotherapy may also increase absorption and cross-presentation of neoplastic antigens [37].

Another manner of antineoplastic therapy involves chemotherapy used in solid tumours before and after surgery (termed the neoadjuvant and adjuvant therapy) and in the first choice in lymphomas and leukaemias. Several effective combinations of chemotherapeutic agents were selected [11, 61], occasionally leading to a complete cure.

Chemotherapy used to be applied repeatedly. The principal problem involves low specificity of most frequently applied chemotherapeutic agents. Nevertheless, in some cases chemotherapeutic agents augment antineoplastic resistance [62, $124,109)$. A great energy is devoted to selection of the more specific drugs on the basis of knowledge involving genetic lesions, most frequently taking place in specific types of tumours $[105,122,152]$. For example, in CML in which neoplastic cells manifest a translocation leading to development of a fusion BCRABL gene, a specific inhibitor of tyrosine kinase termed imatinib (commercial name of Gleevec) provides good clinical effects in chronic phase of the disease [7, 97, 156]. However, such direction of the therapy manifests limitations reflecting extensive variability of genomes in the neoplastic cells [69] and in the patients neoplastic cells may appear which are resistant to the specific drug [156]. In such situations new generations of drugs are used and new sequences of their administration, which occasionally yields positive results. Thus, the system involves permanent search for new drugs, acting on the continuously modifying in the patient neoplastic cells.

In the search for specificity of the applied drugs monoclonal antibodies are used, which decrease mass of the tumour. Occasionally, these are chimeric (human/mouse) or humanised antibodies (human antibodies with mouse fragments in the hypervariable regions, binding the antigen), directed at surface antigens (markers) on neoplastic cells. The aim is similar: to decrease number of neoplastic cells using specifically targeted antibodies, with possibly minimum damage to the immune system. The classical antibody used in antineoplastic therapy involves immunoglogulins directed at CD20 protein, specifically expressed in the surface of B lymphocytes, inact or neoplastically transformed (leukaemias and B-cell lymphomas). The clinically used monoclonal anti-CD20 antibodies include 
rytuxymab, human-mouse chimeric antibody (RTX) [110, 141], ofatumumab, human monoclonal antibody directed against both the small and the large extracellular loop of CD20 antigen [5], glycosylated anti-CD20 antibodies [6, 100, 128].

In presence of complement proteins in the plasma and in intercellular fluids binding of the antibody to a neoplastic or a normal cell induces in such a cell apoptosis along the exogenous pathway. Also cells of immune system recognise cells which bound antibodies due to presence of immunoglobulin heavy chains on their surface. The „protective” cells, such as NK cells, neutrophils, monocytes carry surface receptors for Fc parts of immunoglobulin chains, bind to the „labelled” cells and kill them, which is defined as antibody-dependent cell cytotoxicity (ADCC). Examples of antibodies used in tumour immunotherapy are presented in table 1.

TABLE 1. Examples of antibodies clinically used for destruction of neoplastic cells

\begin{tabular}{|c|c|c|c|}
\hline ANTIBODY & ANTIGEN & TARGETED TUMOUR & $\begin{array}{c}\text { TYPE OF } \\
\text { ANTIBODY }\end{array}$ \\
\hline Rutiximab & $\mathrm{CD} 20$ & B-CLL*, NHL & chimeric \\
\hline Alemtuzumab & CD52 & B-CLL & humanised \\
\hline Ibritumomab tiuxetan & $\mathrm{CD} 20$ & NHL & $\begin{array}{l}\text { mouse with } \\
{ }^{90} \mathrm{Y} \text { or }{ }^{111} \mathrm{In}\end{array}$ \\
\hline Tositumomab & $\mathrm{CD} 20$ & NHL & humanised \\
\hline Cetuximab & EGFR & $\begin{array}{l}\text { colorectal carcinoma, head/neck } \\
\text { carcinoma }\end{array}$ & chimeric \\
\hline Panitumumab & EGFR & colorectal carcinoma & humanised \\
\hline Catumaxomab & $\begin{array}{l}\text { CD3, } \\
\text { EpCAM }\end{array}$ & $\begin{array}{l}\text { exudate of EpCAM to peritoneum } \\
\text { with neoplastic cells }\end{array}$ & mouse/rat hybrid \\
\hline Ofatumumab & $\mathrm{CD} 20$ & B-CLL & humanised \\
\hline Pertuzumab & HER2 & breast carcinoma & humanised \\
\hline Obinutuzumab & $\mathrm{CD} 20$ & B-CLL, B-cell lymphomas** & $\begin{array}{l}\text { humanised, } \\
\text { glycosylated Fc }\end{array}$ \\
\hline
\end{tabular}

* - exerts cytotoxicity mainly due to activation of complement, ** - exerts cytotoxicity mainly due to ADCC reaction

As can be found, currently a physician in the clinic has at his disposal several antibodies against various tumour cells, e.g. anti-CD52 (Alemtuzumab, leukaemias, lymphomas) [112], anti-HER2 (Herceptin, breast carcinoma), antibody specific for the receptor for human epidermal growth factor (EGFR) type 2 (Erbb2) of for the receptor for epidermal grpwth factor, EGFR1 (Cetuximab, Panitumumab, colorectal 
carcinoma, lung carcinoma) [56]. Also for a long time therapies have been applied in which antibodies administered to patients were linked to isotopes (Ibritumomab). Attempts were also made to use bacterial toxins or to amplify with them effects of antibodies [42, 133].

As already mentioned above, the early stages of therapy aim at decreasing mass ot the tumour, which in addition partially unblocks systemic inhibition of immune defense, e.g. unblocks maturation of T lymphocytes in the thymus [63, 66, 67]. This probably results from competition of leukaemic cells with normal lymphocytes for space in the thymus $(12,12 \mathrm{a})$. The thymus provides the site for maturation of $\mathrm{T}$ lymphocytes, including Treg, also in an adult body $[12,96]$.

\section{DISTURBANCES IN IMMUNE SYSTEM IN SOLID TUMOURS AS WELL AS IN LEUKAEMIAS AND LYMPHOMAS}

Following a routine anti-neoplastic treatment, remains of cancer cells still reside in the host. They should be removed by immune system of the host, mainly by lymphocytes T. However, the remaining neoplastic cells block the directed against them local action of cytotoxic lymphocytes.

Lymphocytes T continuously monitor ,correctness” of cellular protein structures, which allows them to remove pathogens and maintain body homeostasis. In order to be able to recognise the presented epitope (antigenc determinant), created by a protein fragment of 8-10 amino acids together with MHC class I the lymphocytes $\mathrm{T}$ must become activated to the effector response. For this purpose they require two signals. The first involves recognition of the epitope and binding by receptor on $\mathrm{T}$ lymphocyte (TCR) of antigenic determinant, presented by antigen presenting cells (APC) together with histocompatibility antigens. The other signal is provided by parallel interaction between $\mathrm{CD} 28$ protein on a lymphocyte $\mathrm{T}$ with ligands $\mathrm{B} 7$ (B7.1, CD80 and B7.2, CD86] in APC cell [126]. The process is termed a co-stimulation [15]. The interactions result in activation of the recognising the epitope lymphocytes $\mathrm{T}, \mathrm{CD}^{+}$and $\mathrm{CD} 8^{+}$, which includes their proliferation and ability to induce apoptosis in the target cells or activation of dendritic cells [DC) using cytokines.

The process inverse to co-stimulation involves inhibition of co-stimulation or co-inhibition, taking place with involvement of at least two groups of molecules: (a)superfamily of immunoglobulin receptors [immunoglobulin super family, IgSF) and (b) superfamily of TNF receptors (TNFR super family) [15]. The first group of molecules (IgSF) resembles in structure chains of antibodies with duistinguishable $\mathrm{IgV}$ and $\mathrm{IgFc}$ domains [153]. The group encompasses stimulatory co-receptors CD28, ICOS, and co-inhibitory receptors: CTLA4, PD-1, LAG3, TIM3, BTLA, VISTA, CD160. Co-receptors of the second group (TNFR SF) exhibit stimulatory properties and the group includes molecules of GITR, OX-40, CD30, CD40 and 
4-1BB [116]. The mentioned co-receptors fulfil also important functions in viral infections (CD40], e.g. in influenza infection [157]. At present, antibodies are produced directed against co-stimulatory molecules (dacetuzumab, anti-CD40) and co-inhibitory proteins, aiming at influencing their control over immune responses [45]. The antibodies are tested using both in vitro and animal models. Clinical trials have also been started on patients. Such a local influence on activity of the immune system used to be termed a control of checkpoints of lymphocyte T activation.

As mentioned above, co-stimulation of lymphocyte $\mathrm{T}$ incompasses recognition of the epitope and it is required for induction of a series of cell divisions of the recognising lymphocyte, its capacity to induce apoptosis in the target cell and for expression of cytokines. Of the recognition signal requires more time, e.g. due to presence of cancer cells in vicinity of $\mathrm{T}$ lymphocytes, on the surface of activated lymphocytes T CTLA-4 protein (cytotoxic T lymphocyte antygen 4, CD152) appears. CTLA-4 interacts with molecules B7 in dendritic cells and the remaining APC, manifesting a higher affinity for them than CD28 protein does. Thus, CTLA4 protein preferentially binds to the B7 molecules, blocking binding of CD28. Resting lymphocytes T manifest low expression of CTLA-4 protein or are devoid of it while higher expression of the protein on lymphocytes $\mathrm{T}$ develops following their activation [38].However, interaction with CTLA-4 does not transmit the costimulatory signal, as it happens in effect of the interaction with CD28 and in such a situation lymphocyte $\mathrm{T}$ does not acquire cytotoxic properties toward the target, cancer cells $[72,119]$. The appearance of CTLA-4 on activated lymphocytes $\mathrm{T}$ involves a regulatory process, which inhibits the extending activation of lymphocytes $T$ and which depends on several variables [118]. In normal conditions such appearance prevents processes of allergy, hypersensitivity due to the extended in time process of immune "defense". However, in parallel, this is also a process which inhibits defense against tumours, due to numerous, similar to CTLA-4 coinhibitory molecules which appear on lymphocytes $\mathrm{T} \mathrm{CD} 4^{+}$, on around every other lymphocyte $\mathrm{T} \mathrm{CD8} 8^{+}$, on Treg lymphocytes, but also on lymphocytes $\mathrm{B}$ and NK lymphocytes $[4,15,119,134]$. The CTLA-4 molecules are mainly accumulated in cytoplasm of the activated cells. Appearance of the molecules on the lymphocyte surface is controlled by interactions with microenvironment which surrounds the cells [148]. Another system inhibiting activity of lymphocytes was also described, the PD-1/PD-L1 system. Lymphocytes T activated in a neoplastic process or a nonneoplastic process release INF $\gamma$, which induces production of ligands: PD-L1 (CD274] and PD-L2 [CD273] by cancer cells, if they exist in the neighbourhood [129]. Coupling of PD-L1 or PD-L2 ligands to lymphocytes T with expression of co-inhibitory receptors, defined as PD-1 (Programmed cell Death protein 1) [13], results in inhibition of the stimulation, leads to blocked production of cytokines, less extensive proliferation of lymphocytes and less pronounced lysis of target cells. The mechanism results in local anergy of lymphocytes $\mathrm{T}$ in tumours. 
The cytotoxic cells forming the CTLs (cytotoxic T lymphocytes) pool encompass Tc lymphocytes $\left(\mathrm{CD}^{+}\right)$, NK cells, NKT and also some Th lymphocytes [CD4 $\left.{ }^{+}\right)$. In our own studies the altered numbers of cytotoxic lymphocytes were confirmed within lungs in patients with lung carcinoma, as compared to healthy individuals. A profile of cells present in bronchoalveolar lavage (BAL) fluid was prepared and lymphocyte subpopulations were examined by flow cytometry. In patients a significantly higher proportion of lymphocytes $\mathrm{T}$ and of $\mathrm{CD} 8^{+}$lymphocytes and a reduced percentage of $\mathrm{CD}^{+}$lymphocytes and a reduced ratio of lymphocytes $\mathrm{T}$ $\mathrm{CD}^{+} / \mathrm{CD}^{+}[25,47]$. In the same patients lymphocyte populations were examined in peripheral blood and reverse alterations were detected: proportion of $\mathrm{CD} 8^{+}$ lymphocytes in the blood was lower in patients with lung carcinoma than in normal individuals while the $\mathrm{Th} / \mathrm{Tc}$ ratio was higher $[25,47]$. Similar results were obtained in a study of very numerous group of 140 patients, in whom lymphocyte typing was performed using immunocytochemistry [23]. The assumption seems justified that lymphocytes defined in BAL reflect composition of TIL infiltrate in the tumour. Importantly, our observations were made before start of treatment and they illustrate condition which probably becomes altered during development of the cancer and, even more, during therapy. Numerous studies conducted in patients with solid tumours, including lung carcinoma confirm positive prognostic significance of $\mathrm{CD} 8^{+}$lymphocytes infiltrate at the site of a tumour [28]. The anti-neoplastic reaction was demonstrated also to be modified through the effect on migratory potential of lymphocytes in the extracellular matrix of a tumour. The study of H. Salmon et al. presence of some mechanical barrier around a focus of cancerous cells which restricted access of inflammatory cells and document functional role of extracellular matrix in the process [115].

Similarly to other neoplastic hyperplasias, in cancer carcinoma presentation of antigens by APC cells manifests a key importance. The mechanism of lymphocyte activation is similar and similar is the role of the suppressory CTLA-4 molecule. CTLA-4 appears on effector T lymphocytes in the environment of the cancer and it blocks transmission of the signal from the APC cell, in this way blocking the cytotoxic effect. On the other hand the function of CTLA-4 on T regulatory cells (Treg) in tumour environment is distinct $[8,29,76,117]$. CTLA-4 is continuously present on Treg and augments suppressory function of the cells. The role of regulatory cells has been well described and in several studies the cells were proved to be present in high numbers in neoplastic infiltrates and to play a significant role inhibiting antineoplastic response [27]. The suppressory function of Treg in tumour environment is linked to activity of Foxp3 transcription factor, also used for identification of Treg. In numerous studies on pulmonary carcinoma a negative prognostic significance of presence of Treg with expression of Foxp3 was documented [60, 103, 137]. Confirmation of Foxp3 expression in regional lymph nodes, even of clinically free of metastases provides a negative prognostic factor [43]. 


\section{ROLE OF NEOPLASTIC CELLS IN INHIBITION OF IMMUNE SYSTEM ACTIVITY}

Anti-neoplastic response becomes actively altered by cancer cells [34, 70, 71]. The alteration takes place through the mechanism of modification affecting the environment in which the cancer develops, through secretion of suppressory cytokines, which stimulate cells which inhibit inflammatory response and through an increased expression of ligands for receptors of suppression and apoptosis (PDL1, PD-L2, Fas-L) on cytotoxic cells [53, 58, 139]. In inhibition of immune system response to tumour development disappearance of cytotoxic lymphocytes and inhibition of their function are significant. Among other, an increased prevalence of apoptosis takes place among protective cells. One of the mechanisms involves the Fas/FasL receptor pathway. In patients with cancer the circulating $\mathrm{CD}_{4}^{+}$and $\mathrm{CD}^{+}$lymphocytes exhibit markedly augmented expression of Fas receptor, which points to their susceptibility for apoptosis, which can be noted after binding the ligand on cancer cells $[24,51]$. In our studies we documented an increased number of lymphocytes with expression of Fas in tobacco smokers and patients suffering from pulmonary chronic obturative disease (PCOD), which may point to suppression of the immune system and an augmented risk of pulmonary cancer development [24, 49].

The anti-neoplastic defense engages also cells of myeloid line but hey exhibit mainly suppressive functions. In recent years two populations of macrophages, M1 and M2 were distinguished. M1 macrophages fulfil mainly immunostimulatory functions producing as effector cells significant amounts of pro-inflammatory cytokines (among other they produce IL-12] and participate in phagocytosis. In turn, M2 macrophages exhibit immunosuppressory functions, they promote angiogenesis and modelling of their environment [84]. In the environment of a solid tumour M1 macrophages stimulated by LPS and IFN- $\gamma$ activate the antineoplastic response but, unfortunately, they are predominated by M2 cells which form the main population among tumour associated macrophages (TAM) and cooperate with cytokines IL-4, IL-10, IL-13 and TGF $\beta$ [9, 81, 94]. Moreover, the M2 population is known to co-operate with regulatory cells and IL-17 interleukin, capable of controlling immune responses [79]. The TAM population can be examined in dissected lung cancers while in advanced tumours macrophages can be obtained using the BAL approach. Employing this technique a significantly „handicapped macrophage function was demonstrated in pulmonary carcinoma in response to interferon" [18].

A pronounced suppressor function in tumour microenvironment is played by myeloid-derived suppressor cells (MDSCs), activated by numerous locally secreted cytokines. The MDSCs are capable of controlling immune responses, they modulate lymphocyte function by production of nitrogen oxide (NO), free 
oxygen radicals (ROS), TGF $\beta$ and PGE2 and they reduce availability of amino acids for effector cells by competitive usage of substrates [131, 132]. Function of MDSCs is linked also to the epithelial-mesenchymal transformation (EMT) which promotes penetration of cancer cells and angiogenesis [130]. Even if significance of macrophages and MDSCs for immune responses has been defined no specific treatment is available which would restrict their function while attempts to inhibit them by enzymatic approaches are at the stage of studies.

Cancer and inflammatory cells in the tumour environment are capable of releasing substances of immunosuppressive action. One of the best known cytokines exerting such an influence involves the transforming growth factor, TGF $\beta$, identified in augmented concentrations in tumours, in cultures of tumour cells and in BAL fluids originating from patients with lung cancer [9]. The main suppressive activity [44] affects function of NK cells and cytotoxic T lymphocytes, differentiation of helper cells toward Th2 and maintenance of Treg differentiation [143]. In addition, cancer cells due to loss of receptors for the factor become insensitive to its inhibitory function. The function of TGF $\beta$ is labile, dependent on local conditions and in first stages of cancer development to favourable for the host [107]. Currently attempts continue to take advantage of new forms of immune modification in therapy, closer described in the second part of this paper.

\section{ACKNOWLEDGEMENTS}

This work was supported by the European Union structural funds and the Innovative Economy Operational Program POIG.01.01.02-00-109/09-00

\section{REFERENCES}

[1] Aerts JG, Hegmans JP. Tumor-specific cytotoxic T cells are crucial for efficacy of immunomodulatory antibodies in patients with lung cancer. Cancer Res 2013; 73(8): 2381-2388.

[2] Amarante-Mendes GP, GrifFith TS. Therapeutic applications of TRAIL receptor agonists in cancer and beyond. Pharmacol Ther 2015, 155: 117-31.

[3] Arvelo F, Sojo F, Cotte C. Biology of colorectal cancer. Ecancermedicalscience 2015; 9:520.

[4] Berman D, Korman A, Peck R, Feltquate D, Lonberg N, Canetta R. The development of immunomodulatory monoclonal antibodies as a new therapeutic modality for cancer: the Bristol-Myers Squibb experience. Pharmacol Ther 2015; 148: 132-153.

[5] Bologna L, Gotti E, Da RF, Intermesoli T, Rambaldi A, Introna M et al. Ofatumumab is more efficient than rituximab in lysing $\mathrm{B}$ chronic lymphocytic leukemia cells in whole blood and in combination with chemotherapy. J Immunol 2013; 190(1): 231-239.

[6] Bologna L, Gotti E, Manganini M, Rambaldi A, Intermesoli T, Introna M et al. Mechanism of action of type II, glycoengineered, anti-CD20 monoclonal antibody GA101 in B-chronic lympho- 
cytic leukemia whole blood assays in comparison with rituximab and alemtuzumab. J Immunol 2011; 186(6): 3762-3769.

[7] Bolton-Gillespie E, Schemionek M, Klein HU, Flis S, Hoser G, Lange T et al. Genomic instability may originate from imatinib-refractory chronic myeloid leukemia stem cells. Blood 2013; 121(20): 4175-4183.

[8] Brandhorst G, Petrova DT, Weigand S, Eberle C, von AN, Schmitz J et al. Lack of correlation between Treg quantification assays in inflammatory bowel disease patients. World J Gastroenterol 2015; 21(11): 3325-3329.

[9] Burkholder B, Huang RY, Burgess R, Luo S, Jones VS, Zhang W et al. Tumor-induced perturbations of cytokines and immune cell networks. Biochim Biophys Acta 2014; 1845(2): 182-201.

[10] Calpe E, Purroy N, Carpio C, Abrisqueta P, Carabia J, Palacio C et al. ZAP-70 promotes the infiltration of malignant B-lymphocytes into the bone marrow by enhancing signaling and migration after CXCR4 stimulation. PLoS One 2013; 8(12): e81221.

[11] Capelletto E, Novello S, Scagliotti GV. First-line therapeutic options for advanced non-small-cell lung cancer in the molecular medicine era. Future Oncol 2014; 10(6): 1081-1093.

[12] Caramalho I, Nunes-Cabaco H, Foxall RB, Sousa AE. Regulatory T-Cell Development in the Human Thymus. Front Immunol 2015; 6: 395.

[13] Martins VC, Busch K, Juraeva D, Blum C, Ludwig C, Rasche V, Lasitschka F, Mastitsky SE, Brors B, Hielscher T, Fehling HJ, Rodewald HR. Cell competition is a tumour suppressor mechanism in the thymus. Nature. 2014 May22; 509(7501): 465-70.

[14] Carbognin L, Pilotto S, Milella M, Vaccaro V, Brunelli M, Calio A et al. Differential Activity of Nivolumab, Pembrolizumab and MPDL3280A according to the Tumor Expression of Programmed Death-Ligand-1 (PD-L1): Sensitivity Analysis of Trials in Melanoma, Lung and Genitourinary Cancers. PLoS One 2015; 10(6) :e0130142.

[15] Catusse J, Leick M, Groch M, Clark DJ, Buchner MV, Zirlik K et al. Role of the atypical chemoattractant receptor CRAM in regulating CCL19 induced CCR7 responses in B-cell chronic lymphocytic leukemia. Mol Cancer 2010; 9: 297.

[16] Chen L, Fuies DB. Molecular mechanisms of T cell co-stimulation and co-inhibition. Nat Rev Immunol 2013; 13(4): 227-242.

[17] Colussi D, Brandi G, Bazzoli F, Ricciardiello L. Molecular pathways involved in colorectal cancer: implications for disease behavior and prevention. Int J Mol Sci 2013; 14(8): 16365-16385.

[18] Crassini K, Mulligan SP, Best OG. Targeting chronic lymphocytic leukemia cells in the tumor microenviroment: A review of the in vitro and clinical trials to date. World J Clin Cases 2015; 3(8): 694-704.

[19] Dabrowska M, Grubek-Jaworska H, Hoser G, Domagala-Kulawik J, Krenke R, Chazan R. Effect of IFN-gamma stimulation on expression of intercellular adhesion molecule-1 (ICAM-1) on alveolar macrophages in patients with non-small cell lung cancer. J Interferon Cytokine Res 2006; 26(3): 190-195.

[20] Danilov AV, Soderquist RS, Bates DJ, Eastman A. Toward a cure for chronic lymphocytic leukemia: an attack on multiple fronts. Expert Rev Anticancer Ther 2013; 13(9): 1009-1012.

[21] Didkowska J, Manczuk M, McNeill A, Powles J, Zatonski W. Lung cancer mortality at ages 3554 in the European Union: ecological study of evolving tobacco epidemics. BMJ 2005; 331(7510): 189-191.

[22] Dillon PM, Olson WC, Czarkowski A, Petroni GR, Smolkin M, Grosh WW et al. A melanoma helper peptide vaccine increases Th1 cytokine production by leukocytes in peripheral blood and immunized lymph nodes. J Immunother Cancer 2014; 2: 23.

[23] Domagala-Kulawik J. Effects of cigarette smoke on the lung and systemic immunity. J Physiol Pharmacol 2008; 59 Suppl 6: 19-34.

[24] Domagala-Kulawik J, Guzman J, Costabel U. Immune cells in bronchoalveolar lavage in peripheral lung cancer--analysis of 140 cases. Respiration 2003; 70(1): 43-48. 
[25] Domagala-Kulawik J, Hoser G, Dabrowska M, Chazan R. Increased proportion of Fas positive CD8+ cells in peripheral blood of patients with COPD. Respir Med 2007; 101(6): 1338-1343.

[26] Domagala-Kulawik J, Hoser G, Droszcz P, Kawiak J, Droszcz W, Chazan R. T-cell subtypes in bronchoalveolar lavage fluid and in peripheral blood from patients with primary lung cancer. Diagn Cytopathol 2001; 25(4): 208-213.

[27] Domagala-KulawiK J, Osinska I. (Immune alterations in lung cancer - the new therapeutic approach). Pneumonol Alergol Pol 2014; 82(3): 286-299.

[28] Domagala-Kulawik J, Osinska I, Hoser G. Mechanisms of immune response regulation in lung cancer. Transl Lung Cancer Res 2014; 3(1): 15-22.

[29] Donnem T, Hald SM, Paulsen EE, Richardsen E, Al-Saad S, Kilvaer TK et al. Stromal CD8+ T-cell Density-A Promising Supplement to TNM Staging in Non-Small Cell Lung Cancer. Clin Cancer Res 2015; 21(11): 2635-2643.

[30] Dummer CD, Carpio VN, Goncalves LF, Manfro RC, Veronese FV. FOXP3+ regulatory T cells: from suppression of rejection to induction of renal allograft tolerance. Transpl Immunol 2012; 26(1): 1-10.

[31] Dunn GP, Bruce AT, IKeda H, Old LJ, Schreiber RD. Cancer immunoediting: from immunosurveillance to tumor escape. Nat Immunol 2002; 3(11): 991-998.

[32] ERS. European Lung White Book. ERS ed. 2014.

[33] Fossati V, Kumar R, SNoeck HW. Progenitor cell origin plays a role in fate choices of mature B cells. J Immunol 2010; 184(3): 1251-1260.

[34] Franceschi C, Bonafe M, Valensin S, Olivieri F, De LM, Ottaviani E et al. Inflamm-aging. An evolutionary perspective on immunosenescence. Ann N Y Acad Sci 2000; 908: 244-254.

[35] Frydecka I, Kosmaczewska A, Bocko D, Ciszak L, Wolowiec D, Kuliczkowski K et al. Alterations of the expression of T-cell-related costimulatory CD28 and downregulatory CD152 (CTLA-4) molecules in patients with B-cell chronic lymphocytic leukaemia. Br J Cancer 2004; 90(10): 2042-2048.

[36] Fulda S, Debatin KM. Extrinsic versus intrinsic apoptosis pathways in anticancer chemotherapy. Oncogene 2006; 25(34): 4798-4811.

[37] Fulop T, Larbi A, Witkowski JM, McElhaney J, Loeb M, Mitnitski A et Al. Aging, frailty and age-related diseases. Biogerontology 2010; 11(5): 547-563.

[38] Gameiro SR, Jammen ML, Wattenberg MM, Tsang KY, Ferrone S, Hodge JW. Radiation-induced immunogenic modulation of tumor enhances antigen processing and calreticulin exposure, resulting in enhanced T-cell killing. Oncotarget 2014; 5(2): 403-416.

[39] Gardner D, Jeffery LE, Sansom DM. Understanding the CD28/CTLA-4 (CD152) pathway and its implications for costimulatory blockade. Am J Transplant 2014; 14(9): 1985-1991.

[40] Gialeli C, Theocharis AD, Karamanos NK. Roles of matrix metalloproteinases in cancer progression and their pharmacological targeting. FEBS J 2011; 278(1): 16-27.

[41] Gounari M, Ntoufa S, Apollonio B, Papakonstantinou N, Ponzoni M, Chu CC et al. Excessive antigen reactivity may underlie the clinical aggressiveness of chronic lymphocytic leukemia stereotyped subset \#8. Blood 2015; 125(23): 3580-3587.

[42] Grabinska K, Pelak M, Wydmanski J, Tukiendorf A, D’Amico A. Prognost ic value and cl inical correlations of 18 -fluorodeoxyglucose metabolism quantifiers in gastric cancer. World J Gastroenterol 2015; 21(19): 5901-5909.

[43] Gryzik M, Grzywocz Z, Wasilewska D, Kawiak J, Stachowiak R, Bielecki J et al. Human lymphocytic B-leukemia cell line treatment with the bacterial toxin listeriolysin $\mathrm{O}$ and rituximab (anti-CD20 antibody): Effects of similar localization of their receptors. Int J Immunopathol Pharmacol 2015; 28(3): 329-340.

[44] Hanagiri T, Shigematsu Y, Shinohara S, Takenaka M, Oka S, Chikaishi Y et al. Clinical significance of the frequency of regulatory $\mathrm{T}$ cells in regional lymph node lymphocytes as a prognostic factor for non-small-cell lung cancer. Lung Cancer 2013; 81(3): 475-479.

[45] Harder T, Guttex K, Philipsen L, Simeoni L, Schraven B, Reinhold D. Selective targeting of transforming growth factor-beta1 into TCR/CD28 signalling plasma membrane domains silences $\mathrm{T}$ cell activation. Cell Commun Signal 2014; 12: 74. 
[46] Hassan SB, Sorensen JF, Olsen BN, Pedersen AE. Anti-CD40-mediated cancer immunotherapy: an update of recent and ongoing clinical trials. Immunopharmacol Immunotoxicol 2014; 36(2): 96-104.

[47] Hodi FS, O’Day SJ, McDermott DF, Weber RW, Sosman JA, HaAnen JB et al. Improved survival with ipilimumab in patients with metastatic melanoma. N Engl J Med 2010; 363(8): 711-723.

[48] Hoser G, Domagala-Kulawik J, Droszcz P, Droszcz W, Kawiak J. Lymphocyte subsets differences in smokers and nonsmokers with primary lung cancer: a flow cytometry analysis of bronchoalveolar lavage fluid cells. Med Sci Monit 2003; 9(8): BR310-BR315.

[49] Hoser G, KAWIAK J. A trypsin inhibitor isolated from lymphatic leukemia cells. Biomed Biochim Acta 1986; 45(9): 1127-1133.

[50] Hoser G, Kawiak J, Domagala-Kulawik J, Kopinski P, Droszcz W. Flow cytometric evaluation of lymphocyte subpopulations in BALF of healthy smokers and nonsmokers. Folia Histochem Cytobiol 1999; 37(1): 25-30.

[51] Hoser G, Majsterek I, Romana DL, Slupianek A, Blasiak J, Skorski T. Fusion oncogenic tyrosine kinases alter DNA damage and repair after genotoxic treatment: role in drug resistance? Leuk Res 2003; 27(3): 267-273.

[52] Hoser G, Wasilewska D, Domagala-Kulawik J. Expression of Fas receptor on peripheral blood lymphocytes from patients with non-small cell lung cancer. Folia Histochem Cytobiol 2004; 42(4): 249-252.

[53] Howington JA, Blum MG, Chang AC, Balekian AA, Murthy SC. Treatment of stage I and II nonsmall cell lung cancer: Diagnosis and management of lung cancer, 3rd ed: American College of Chest Physicians evidence-based clinical practice guidelines. Chest 2013; 143(5 Suppl): e278S-e313S.

[54] Huang G, Nishimoto K, Yang Y, Kleinerman ES. Part icipat ion of the Fas/FasL signal ing pat hway and the lung microenvironment in the development of osteosarcoma lung metastases. Adv Exp Med Biol 2014; 804: 203-217.

[55] Hus I, Kawiak J, Hoser G, Tabarkiewicz J, Radej S, Dmoszynska A et al. SCiD mice model in vivo evaluation of autologous and allogeneic dendritic cells activity on B-cell chronic lymphocytic leukemia. Folia Histochem Cytobiol 2009; 47(4): 563-570.

[56] Hus I, Schmitt M, Tabarkiewicz J, Radej S, Wojas K, Bojarska-Junak A et al. Vaccination of B-CLL patients with autologous dendritic cells can change the frequency of leukemia antigen-specific CD8+ $\mathrm{T}$ cells as well as $\mathrm{CD} 4+\mathrm{CD} 25+\mathrm{FoxP} 3+$ regulatory $\mathrm{T}$ cells toward an antileukemia response. Leukemia 2008; 22(5): 1007-1017.

[57] Hutchinson RA, Adams RA, McArt DG, Salto-Tellez M, Jasani B, Hamilton PW. Epidermal growth factor receptor immunohistochemistry: new opportunities in metastatic colorectal cancer. J Transl Med 2015; 13: 217.

[58] Jett JR, Schild SE, Kesler KA, Kalemkerian GP. Treatment of small cell lung cancer: Diagnosis and management of lung cancer, 3rd ed: American College of Chest Physicians evidence-based clinical practice guidelines. Chest 2013; 143(5 Suppl): e400S-e419S.

[59] Jewett A, Tseng HC. Tumor induced inactivation of natural killer cell cytotoxic function; implication in growth, expansion and differentiation of cancer stem cells. J Cancer 2011; 2:443-457.

[60] KaLia M. Biomarkers for personalized oncology: recent advances and future challenges. Metabolism 2015; 64(3 Suppl 1): S16-S21.

[61] Karanikas V, Speletas M, Zamanakou M, Kalala F, Loules G, Kerenidi T et al. Foxp3 expression in human cancer cells. J Transl Med 2008; 6: 19.

[62] Kasprzyk M, Slawinski G, Musik M, Marciniak L, Dyszkiewicz W, Piwkowski C et al. Completion pneumonectomy and chemoradiotherapy as treatment options in local recurrence of non-small-cell lung cancer. Kardiochir Torakochirurgia Pol 2015; 12(1): 18-25.

[63] Kawalec M, Skorski T, Hoser G. Immunogenicity of cyclophosphamide-treated tumor cells. Arch Immunol Ther Exp (Warsz ) 1988; 36(3): 345-350.

[64] Kawiak J, Hoser G, Malendowicz LK, Miks B, Skurzak H. Thymocyte and splenocyte subpopulations in normal and leukemia-bearing mice after adrenalectomy. Folia Histochem Cytobiol 1996; 34(2): $75-78$ 
[65] Kawiak J, Hoser G, Miks B, Pojda Z, Sobiczewska A, Machaj E et al. Populations of thymocytes and peripheral blood leucocytes in leukaemia-bearing mice treated with G-CSF. Immunol Cell Biol 1996; 74(2): 163-166.

[66] Kawiak J, Hoser G, Skorski T. Apoptosis and some of its medical implications. Folia Histochem Cytobiol 1998; 36(3): 99-110.

[67] KawiaK J, Kawalec M. Leukemia L 1210 cells induce depletion of Lyt 2+ thymocytes. Folia Histochem Cytobiol 1990; 28(1-2): 15-17.

[68] Kawiak J, Kawalec M, Hoser G, Miks B, Skorski T, Pojda Z et al. Changes of thymocyt e subpopulations induced by activities diffusing from leukemia L1210 cells. Thymus 1991; 18(3):185-192.

[69] Kessenbrock K, Plaks V, Werb Z. Matrix metalloproteinases: regulators of the tumor microenvironment. Cell 2010; 141(1): 52-67.

[70] Kim TH, LesLie P, ZhANG Y. Ribosomal proteins as unrevealed caretakers for cellular stress and genomic instability. Oncotarget 2014; 5(4): 860-871.

[71] Kosmaczewska A, Bocko D, Ciszak L, Wlodarska-Polinska I, Kornafel J, Szteblich A et al. Dysregulated expression of both the costimulatory CD28 and inhibitory CTLA-4 molecules in PB T cells of advanced cervical cancer patients suggests systemic immunosuppression related to disease progression. Pathol Oncol Res 2012; 18(2): 479-489.

[72] Kovacsovics-Bankowski M, Chisholm L, Vercellini J, Tucker CG, Montler R, Haley D et al. Detailed characterization of tumor infiltrating lymphocytes in two distinct human solid malignancies show phenotypic similarities. J Immunother Cancer 2014; 2(1): 38.

[73] Krummel MF, Allison JP. Pillars article: CD28 and CTLA-4 have opposing effects on the response of $\mathrm{T}$ cells to stimulation. The journal of experimental medicine. 1995. 182: 459-465. J Immunol 2011; 187(7): 3459-3465.

[74] Krysko DV, Agostinis P, Krysko O, Garg AD, Bachert C, Lambrecht BN et al. Emerging role of damage-associated molecular patterns derived from mitochondria in inflammation. Trends Immunol 2011; 32(4): 157-164.

[75] Kүг C, Postow MA. Checkpoint blocking antibodies in cancer immunotherapy. FEBS Lett 2014; 588(2): $368-376$.

[76] Leick M, Catusse J, Follo M, Nibbs RJ, Hartmann Tn, Veelken H et al. CCL19 is a specific ligand of the constitutively recycling atypical human chemokine receptor CRAM-B. Immunology 2010; 129(4): 536-546.

[77] Lin X, Chen M, Liu Y, Guo Z, He X, Brand D et al. Advances in distinguishing natural from induced Foxp3(+) regulatory T cells. Int J Clin Exp Pathol 2013; 6(2): 116-123.

[78] Lindeman Ni, Cagle PT, Beasley MB, Chitale DA, Dacic S, Giaccone G et al. Molecular testing guideline for selection of lung cancer patients for EGFR and ALK tyrosine kinase inhibitors: guideline from the College of American Pathologists, International Association for the Study of Lung Cancer, and Association for Molecular Pathology. J Thorac Oncol 2013; 8(7): 823-859.

[79] Liu J, Fukunaga-Kalabis M, Li L, Herlyn M. Developmental pathways activated in melanocytes and melanoma. Arch Biochem Biophys 2014; 563: 13-21.

[80] Liu L, Ge D, Ma L, Mei J, Liu S, Zhang Q et AL. Interleukin-17 and prostaglandin E2 are involved in formation of an M2 macrophage-dominant microenvironment in lung cancer. J Thorac Oncol 2012; 7(7): 1091-1100.

[81] Lugowska I, Kowalska M, Fuksiewicz M, Kotowicz B, Mierzejewska E, Kosela-Paterczyk H et al. Serum markers in early-stage and locally advanced melanoma. Tumour Biol 2015; 36(11): 8277-85.

[82] MA J, Liu L, Che G, Yu N, DaI F, You Z. The M1 form of tumor-associated macrophages in non-small cell lung cancer is positively associated with survival time. BMC Cancer 2010; 10: 112.

[83] Majsterek I, Blasiak J, Mlynarski W, Hoser G, Skorski T. Does the bcr/abl-mediated increase in the efficacy of DNA repair play a role in the drug resistance of cancer cells? Cell Biol Int 2002; 26(4): 363-370.

[84] Majsterek I, Slupianek A, Hoser G, Skorski T, Blasiak J. ABL-fusion oncoproteins activate multi-pathway of DNA repair: role in drug resistance? Biochimie 2004; 86(1): 53-65. 
[85] Mantovani A, Sozzani S, Locati M, Allavena P, Sica A. Macrophage polarization: tumor-associated macrophages as a paradigm for polarized M2 mononuclear phagocytes. Trends Immunol 2002; 23(11): 549-555.

[86] McCaig AM, Cosimo E, Leach MT, Michie AM. Dasatinib inhibits CXCR4 signaling in chronic lymphocytic leukaemia cells and impairs migration towards CXCL12. PLoS One 2012; 7(11): e48929.

[87] McCarthy BA, Boyle E, Wang XP, Guzowski D, Paul S, Catera R et al. Surface expression of Bcl-2 in chronic lymphocytic leukemia and other B-cell leukemias and lymphomas without a breakpoint $\mathrm{t}(14 ; 18)$. Mol Med 2008; 14(9-10): 618-627.

[88] McDonnell AM, Lesterhuis WJ, Khong A, Nowak AK, Lake RA, Currie AJ et al. Tumor-infiltrating dendritic cells exhibit defective cross-presentation of tumor antigens, but is reversed by chemotherapy. Eur J Immunol 2015; 45(1): 49-59.

[89] Mellstedt H, Vansteenkiste J, Thatcher N. Vaccines for the treatment of non-small cell lung cancer: investigational approaches and clinical experience. Lung Cancer 2011; 73(1): 11-17.

[90] Mellstedt H, Vansteenkiste J, Thatcher N. Vaccines for the treatment of non-small cell lung cancer: investigational approaches and clinical experience. Lung Cancer 2011; 73(1): 11-17.

[91] Milpied P, Nadel B, Roulland S. Premalignant cell dynamics in indolent B-cell malignancies. Curr Opin Hematol 2015; 22(4): 388-396.

[92] Mimura K, Shiraishi K, Mueller A, Izawa S, Kua LF, So J et al. The MaPK pathway is a predominant regulator of HLA-A expression in esophageal and gastric cancer. J Immunol 2013; 191(12): 6261-6272.

[93] Mintern JD, Macri C, Chin WJ, Panozza Se, Segura E, Patterson NL et al. Differential use of autophagy by primary dendritic cells specialized in cross-presentation. Autophagy 2015; 11(6): 906-917.

[94] Mlnarczuk I, Mroz P, Hoser G, Nowis D, Bialy LP, Ziemba H et al. AAF-cmk sensitizes tumor cells to trail-mediated apoptosis. Leuk Res 2004; 28(1): 53-61.

[95] Murdoch C, Giannoudis A, Lewis CE. Mechanisms regulating the recruitment of macrophages into hypoxic areas of tumors and other ischemic tissues. Blood 2004; 104(8): 2224-2234.

[96] Nagasawa T. CXCL12/SDF-1 and CXCR4. Front Immunol 2015; 6:301.

[97] Nazzal D, Gradolatto A, Truffault F, Bismuth J, Berrih-Aknin S. Human thymus medullary epithelial cells promote regulatory T-cell generation by stimulating interleukin-2 production via ICOS ligand. Cell Death Dis 2014; 5: e1420.

[98] Nieborowska-Skorska M, Bialek AP, Nicolaides nC, Iozzo RV, Kawalec M, Calabretta B et al. The influence of phosphorothioate oligodeoxynucleotides on various organs in vivo. Folia Histochem Cytobiol 1996; 34(2): 69-73.

[99] Nieborowska-Skorska M, Hoser G, Kossev P, Wasik MA, Skorski T. Complementary functions of the antiapoptotic protein $\mathrm{A} 1$ and serine/threonine kinase pim-1 in the BCR/ABL-mediated leukemogenesis. Blood 2002; 99(12): 4531-4539.

[100] Nieborowska-Skorska M, Kopinski PK, Ray R, Hoser G, Ngaba D, Flis S et al. Rac2-MRC-cIII-generated ROS cause genomic instability in chronic myeloid leukemia stem cells and primitive progenitors. Blood 2012; 119(18): 4253-4263.

[101] Owen CJ, Stewart DA. Obinutuzumab for the treatment of patients with previously untreated chronic lymphocytic leukemia: overview and perspective. Ther Adv Hematol 2015; 6(4): 161-170.

[102] Palucka K, Banchereau J. Cancer immunotherapy via dendritic cells. Nat Rev Cancer 2012; 12(4): 265-277.

[103] Palucka K, Banchereau J. Dendritic-cell-based therapeutic cancer vaccines. Immunity 2013; 39(1): 38-48.

[104] Petersen RP, Campa MJ, Sperlazza J, Conlon D, Joshi MB, Harpole DH, JR. et al. Tumor infiltrating Foxp3+ regulatory T-cells are associated with recurrence in pathologic stage I NSCLC patients. Cancer 2006; 107(12): 2866-2872.

[105] Pizzurro Ga, Tapia IJ, Sganga L, Podhajcer OL, Mordoh J, Barrio MM. Cyt okine-enhanced mat uration and migration to the lymph nodes of a human dying melanoma cell-loaded dendritic cell vaccine. Cancer Immunol Immunother 2015; 64(11): 1393-1406. 
[106] Popovic R, Shaн MY, Licht JD. Epigenetic therapy of hematological malignancies: where are we now? Ther Adv Hematol 2013; 4(2): 81-91.

[107] Quante M, Tu SP, Tomita H, Gonda T, Wang SS, TaKashi S et al. Bone marrow-derived myofibroblasts contribute to the mesenchymal stem cell niche and promote tumor growth. Cancer Cell 2011; 19(2): 257-272.

[108] Quatromoni JG, Suzuki E, Okusanya O, Judy BF, Bhojnagarwala P, Venegas O et al. The timing of TGF-beta inhibition affects the generation of antigen-specific CD8+ T cells. BMC Immunol 2013; 14: 30 .

[109] Radej S, Rolinski J, Rawicz-Pruszynski K, Bury P, Borowski G, Furmaga J et al. Immunomodelling Characteristics of Mature Dendritic Cells Stimulated by Colon Cancer Cells Lysates. Pol Przegl Chir 2015; 87(2): 71-82.

[110] Radojcic V, Bezak KB, Skarica M, Pletneva Ma, Yoshimura K, Schulick RD et al. Cyclophosphamide resets dendritic cell homeostasis and enhances antitumor immunity through effects that extend beyond regulatory T cell elimination. Cancer Immunol Immunother 2010; 59(1): 137-148.

[111] Ren YR, JiN YD, Zhang ZH, Li L, Wu P. Rituximab treatment strategy for patients with diffuse large B-cell lymphoma after first-line therapy: a systematic review and meta-analysis. Chin Med J (Engl) 2015; 128(3): 378-383.

[112] Rivenbark AG, Stolzenburg S, Beltran AS, Yuan X, Rots MG, Strahl BD et al. Epigenetic reprogramming of cancer cells via targeted DNA methylation. Epigenetics 2012; 7(4): 350-360.

[113] Robak P, Smolewski P, Robak T. Emerging immunological drugs for chronic lymphocytic leukemia. Expert Opin Emerg Drugs 2015; 20(3): 423-447.

[114] Rycaj K, TANG DG. Cell-of-Origin of Cancer versus Cancer Stem Cells: Assays and Interpretations. Cancer Res 2015; 75(19): 4003-4011.

[115] Sabbatini P, Tsuji T, Ferran L, Ritter E, Sedrak C, Tuballes K et al. Phase I trial of overlapping long peptides from a tumor self-antigen and poly-ICLC shows rapid induction of integrated immune response in ovarian cancer patients. Clin Cancer Res 2012; 18(23): 6497-6508.

[116] Salmon H, Franciszkiewicz K, Damotte D, Dieu-Nosjean MC, Validire P, Trautmann A et al. Matrix architecture defines the preferential localization and migration of $\mathrm{T}$ cells into the stroma of human lung tumors. J Clin Invest 2012; 122(3): 899-910.

[117] Sanmamed MF, Pastor F, Rodriguez A, Perez-Gracia JL, Rodriguez-Ruiz ME, Jure-Kunkel M et al. Agonists of Co-stimulation in Cancer Immunotherapy Directed Against CD137, OX40, GITR, CD27, CD28, and ICOS. Semin Oncol 2015; 42(4): 640-655.

[118] Sснмiтt EG, Williams CB. Generation and function of induced regulatory T cells. Front Immunol 2013; 4: 152.

[119] SchneIder H, Rudd CE. Diverse mechanisms regulate the surface expression of immunotherapeutic target ctla-4. Front Immunol 2014; 5: 619.

[120] Shekarian T, Valsesia-Wittmann S, Caux C, Marabelle A. Paradigm shift in oncology: targeting the immune system rather than cancer cells. Mutagenesis 2015; 30(2): 205-211.

[121] Shen X, Zheng JY, Shi H, Zhang Z, Wang WZ. Survivin knockdown enhances gastric cancer cell sensitivity to radiation and chemotherapy in vitro and in nude mice. Am J Med Sci 2012; 344(1): 52-58.

[122] Shibata T. Current and future molecular profiling of cancer by next-generation sequencing. Jpn J Clin Oncol 2015; 45(10): 895-899.

[123] Skirecki T, Hoser G, Kawiak J, Dziedzic D, Domagala-Kulawik J. Flow cytometric analysis of C. Arch Immunol Ther Exp (Warsz ) 2014; 62(1): 67-75.

[124] Skorski T, Nieborowska-Skorska M, Wlodarski P, Perrotti D, Hoser G, Kawiak J et al. Treatment of Philadelphia leukemia in severe combined immunodeficient mice by combination of cyclophosphamide and bcr/abl antisense oligodeoxynucleotides. J Natl Cancer Inst 1997; 89(2): 124-133.

[125] Slupianek A, Hoser G, Majsterek I, Bronisz A, Malecki M, Blasiak J et al. Fusion tyrosine kinases induce drug resistance by stimulation of homology-dependent recombination repair, prolongation of G(2)/M phase, and protection from apoptosis. Mol Cell Biol 2002; 22(12): 4189-4201. 
[126] Smeets RL, Fleuren WW, He X, Vink PM, Wijnands F, Gorecka M et al. Molecular pathway profiling of T lymphocyte signal transduction pathways; Th1 and Th2 genomic fingerprints are defined by TCR and CD28-mediated signaling. BMC Immunol 2012; 13: 12.

[127] Smigielski J, Piskorz L, Talar-Wojnarowska R, Malecka-Panas E, Jablonski S, Brocki M. The estimation of metaloproteinases and their inhibitors blood levels in patients with pancreatic tumors. World J Surg Oncol 2013; 11: 137.

[128] Smoles L. Targeted treatment for chronic lymphocytic leukemia: clinical potential of obinutuzumab. Pharmgenomics Pers Med 2015; 8: 1-7.

[129] Spranger S, Spaapen RM, Zha Y, Williams J, Meng Y, Ha TT et al. Up-regulation of PD-L1, IDO, and $\mathrm{T}(\mathrm{regs})$ in the melanoma tumor microenvironment is driven by CD $8(+) \mathrm{T}$ cells. Sci Transl Med 2013; 5(200): 200ra116.

[130] Srivastava MK, Andersson A, Zhu L, Harris-White M, Lee JM, Dubinett S et al. Myeloid suppressor cells and immune modulation in lung cancer. Immunotherapy 2012; 4(3): 291-304.

[131] Srivastava MK, Dubinett S, Sharma S. Targeting MDSCs enhance therapeutic vaccination responses against lung cancer. Oncoimmunology 2012; 1(9):1650-1651.

[132] Srivastava MK, Zhu L, Harris-White M, Kar UK, Huang M, Johnson MF et al. Myeloid suppressor cell depletion augments antitumor activity in lung cancer. PLoS One 2012; 7(7): e40677.

[133] Stachowiak R, Lyzniak M, Grabowska M, Roeske K, Jagielski T, Bielecki J et al. Cytotoxicity of purified listeriolysin O on mouse and human leukocytes and leukaemia cells. BMC Biotechnol 2014; 14: 77.

[134] Sundar R, Soong R, Cho BC, Brahmer JR, Soo RA. Immunotherapy in the treatment of non-small cell lung cancer. Lung Cancer 2014; 85(2): 101-109.

[135] Tanaka T, Okuya K, Kutomi G, Takaya A, Kajiwara T, Kanaseki T et al. Heat shock protein 90 targets a chaperoned peptide to the static early endosome for efficient cross-presentation by human dendritic cells. Cancer Sci 2015; 106(1): 18-24.

[136] TANG DG. Understanding cancer stem cell heterogeneity and plasticity. Cell Res 2012; 22(3): 457-472.

[137] Tao H, Mimura Y, Aoe K, Kobayashi S, Yamamoto H, Matsuda E et al. Prognostic potential of FOXP3 expression in non-small cell lung cancer cells combined with tumor-infiltrating regulatory $\mathrm{T}$ cells. Lung Cancer 2012; 75(1): 95-101.

[138] Tartour E, Zitvogel L. Lung cancer: potential targets for immunotherapy. Lancet Respir Med 2013; 1(7): 551-563.

[139] Taube JM, Anders RA, Young GD, Xu H, Sharma R, McMiller TL et al. Colocalization of inflammatory response with B7-h1 expression in human melanocytic lesions supports an adaptive resistance mechanism of immune escape. Sci Transl Med 2012; 4(127): $127 \mathrm{ra37.}$

[140] Ten Hacken E, Burger JA. Microenvironment interactions and B-cell receptor signaling in Chronic Lymphocytic Leukemia: Implications for disease pathogenesis and treatment. Biochim Biophys Acta 2016; 1863(3): 401-13.

[141] Teo EC, Chew Y, Phipps C. A review of monoclonal antibody therapies in lymphoma. Crit Rev Oncol Hematol 2016; 97: 72-84.

[142] Tran Janco JM, Lamichinane P, Karyampudi L, KnUtson KL. Tumor-infiltrating dendritic cells in cancer pathogenesis. J Immunol 2015; 194(7): 2985-2991.

[143] Traves PG, Luque A, Hortelano S. Macrophages, inflammation, and tumor suppressors: ARF, a new player in the game. Mediators Inflamm 2012; 2012: 568783.

[144] Urso L, Calabrese F, Favaretto A, Conte P, Pasello G. Critical review about MDM2 in cancer: Possible role in malignant mesothelioma and implications for treatment. Crit Rev Oncol Hematol 2016;97: $220-30$.

[145] Vacchelli E, Aranda F, Eggermont A, Galon J, Sautes-Fridman C, Cremer I et al. Trial Watch: Chemotherapy with immunogenic cell death inducers. Oncoimmunology 2014; 3(1):e27878.

[146] Vardi A, Agathangelidis A, Stalika E, Karypidou M, Siorenta A, Anagnostopoulos A et al. Ant igen Selection Shapes the T-cell Repertoire in Chronic Lymphocytic Leukemia. Clin Cancer Res 2016; 22(1): 167-74. 
[147] WaDe M, Li YC, WAHL GM. MDM2, MDMX and p53 in oncogenesis and cancer therapy. Nat Rev Cancer 2013; 13(2) :83-96.

[148] WaLKeR LS, SANSOM DM. Confusing signals: recent progress in CTLA-4 biology. Trends Immunol 2015; 36(2): 63-70.

[149] Wei S, Wang H, Lu C, Malmut S, Zhang J, Ren S et al. The activating transcription factor 3 protein suppresses the oncogenic function of mutant p53 proteins. J Biol Chem 2014; 289(13): 8947-8959.

[150] Wlodarski P, Wasik M, Ratajczak MZ, Sevignani C, Hoser G, Kawiak J et al. Role of p53 in hematopoietic recovery after cytotoxic treatment. Blood 1998; 91(8): 2998-3006.

[151] Whodkowic D, Skommer J, Darzynkiewicz Z. Cytometry of apoptosis. Historical perspective and new advances. Exp Oncol 2012; 34(3): 255-262.

[152] Yan W, Herman JG, Guo M. Epigenome-based personalized medicine in human cancer. Epigenomics 2016; 8(1): 119-33.

[153] Yaо S, Zhu Y, Chen L. Advances in targeting cell surface signalling molecules for immune modulation. Nat Rev Drug Discov 2013; 12(2): 130-146.

[154] Yonezawa S, Higashi M, Yamada N, Yokoyama S, Kitamoto S, Kitajima S et al. Mucins in human neoplasms: clinical pathology, gene expression and diagnostic application. Pathol Int 2011; 61(12): 697-716.

[155] Zanardelli M, Micheli L, Nicolai R, Failli P, Ghelardini C, Di Cesare ML. Different apoptotic pathways activated by oxaliplatin in primary astrocytes vs. colo-rectal cancer cells. Int J Mol Sci 2015; 16(3): 5386-5399.

[156] Zolnierowicz J, Ambrozek-Latecka M, Kawiak J, Wasilewska D, Hoser G. Monitoring cell proliferation in vitro with different cellular fluorescent dyes. Folia Histochem Cytobiol 2013; 51(3): 193-200.

[157] Zou Q, Wu B, Xue J, Fan X, Feng C, Geng S et al. CD8+ Treg cells suppress CD8+ T cell-responses by IL-10-dependent mechanism during H5N1 influenza virus infection. Eur J Immunol 2014; 44(1): $103-114$.

Jerzy Kawiak

S. Banacha Street $20 / 18$

phone: 661850463

email: jkawiak@ibib.waw.pl 